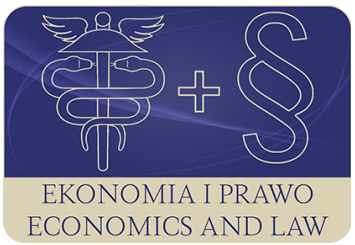

EKONOMIA I PRAWO. ECONOMICS AND LAW

Volume 18, Issue 4, December 2019

p-ISSN 1898-2255, e-ISSN 2392-1625

www.economicsandlaw.pl

ORIGINAL ARTICLE

received 30.03.2019; revised 04.12.2019; accepted 31.12.2019

Citation: Dziemianowicz, R. (2019). Tax policy in OECD countries in 2007-2016: trends and challenges. Ekonomia i Prawo. Economics and Law, 18(4): 425-440.

doi:10.12775/EiP.2019.028.

\title{
Tax policy in OECD countries in 2007-2016: trends and challenges
}

\author{
RYTA DZIEMIANOWICZ \\ University of Bialystok, Faculty of Economics and Finance, Departament of Finance, \\ ul. Warszawska 63, 15-062 Bialystok, Poland \\ $\square$ r.dziemianowicz@uwb.edu.pl \\ (D) orcid.org/0000-0002-7755-9887
}

\begin{abstract}
Motivation: Taxation patterns vary from country to country. The shape of the tax policy was influenced by historical conditions, as well as changes in macroeconomic conditions. An example of this is the recent crisis, during which the measures taken in the area of discretionary tax policy often proved to be a good response to the problems of the economies and facilitated a faster return to the path of growth. At the same time, during the last century, the perception of the role of taxes in economic development changed radically, moving from a legitimate tool used by the state in the development process after World War II, through treating taxes as a 'necessary evil' at the turn of the century, to an instrument conditioning the maintenance of fiscal balance.

Aim: The purpose of this article is to analyze the tax policies implemented in OECD countries, indicate similarities and differences in response to global conditions and identify general trends in the reform of tax systems. The analysis covered OECD countries in 2008-2017. The study utilizes the descriptive method with elements of statistical data analysis. The article was prepared on the basis of literature studies and OECD data.

Results: Economic globalization has changed the dynamics of the legislation process and influenced decision making in the field of tax policy. Although decisions are still made by state parliaments, they not only reflect the needs of the budget, but also ensure the international competitiveness of the tax system and protect against fiscal erosion. It should be remembered, however, that the tax system is defined as a social agreement of sorts, which is concluded between the government and the society. The level and structure of taxation determine the specific 'social balance' achieved between the conflicting interests represented by the two parties to the agreement. This balance should not be disturbed solely in order to cover unitary shortfalls in public revenue in a given year.
\end{abstract}


Keywords: tax policy; tax system; theory taxation

JEL: H2O; H21; H26; H30

\section{Introduction}

In 1904, while speaking in the US Supreme Court, Oliver W. Holmes ${ }^{1}$ said that taxes are the price we pay for living in a civilized society. 115 years have passed since that speech, and the perception of the role of state in social and economic development, including the function of taxes, has changed. This does not mean, of course, that taxes have lost their importance. Rather the contrary - this 'price' for living in a civilized society has significantly increased. At the same time, however, taxes have ceased to have an exclusively fiscal function and have become also an effective instrument for stimulating the economy and redistributing income.

The way in which individual governments have created their tax policies and built their tax systems has never been uniform. The current taxation patterns, similarly to the tax structure, vary and depend on many factors, be they historical, economic or political. However, it appears that in the conditions of globalization, the actions of individual governments within this scope are increasingly similar, especially in the face of economic shocks.

The purpose of this article is to review the tax policies implemented in OECD countries, indicate similarities and differences in response to crises and identify general trends concerning the changes in taxation. The following hypothesis was subject to verification in the study: Tax policies implemented in OECD countries, despite significant differences in the level and structure of taxation, become more and more similar to each other. The analysis covered the years 2007-2016. The study utilizes the descriptive method with elements of statistical data analysis. The article was prepared on the basis of literature studies and OECD database.

Each part of the paper presents a brief description of the evolution of changes in the perception of the role of taxes, with particular emphasis on economic and political events that provoked theoreticians' discussions on the subject and had a significant impact on the directions of tax reforms. In view of the restrictions in force, this review is of rather selective nature. The empirical part presents the tax policies implemented in OECD countries. The focus was mainly on tax changes resulting from the financial crisis of 2008. The level and structure of taxation for the years 2007-2016 were presented. Possible implications for the future tax policy were analyzed, including those resulting from the need to adapt it to the globalization processes.

\footnotetext{
${ }^{1}$ Oliver W. Holmes (1841-1935), Judge at the Supreme Court of the United States.
} 


\section{Evolution of the concept of tax policy and its conditions}

Taxes constitute not only an economic but also a political category. Modern tax systems reflect the relative importance that a society of a given country, through its political institutions, decides to assign to different purposes and the roles that have been 'appointed' to tax instruments in order to achieve these purposes (Bird \& Wilkie, 2012, p. 2). They have been shaped not only as a result of the evolution of the main ideas on taxation, but also global events, both economic and political, which include, without limitation: World War I, the Great Depression, World War II, oil crises, the end of the Cold War as well as the recent economic and fiscal crisis. Undoubtedly, these events had a significant impact both on the development of tax theories, including changes in the perception of the role of state in this respect, as well as on tax practice.

Although the history of taxes is very long, modern tax systems have not begun to emerge until the 20th century, when, under the influence of socioeconomic developments and political events, government demand for public income increased significantly. Still in the second half of the 19th century, Paul Leroy-Beaulieu, based on his knowledge of public finances at that time, claimed that the level of taxation at 5-6\% of GDP can be considered very moderate, approx. $6-12 \%$ of GDP - 'normal', while above $12 \%$ - too high. At the same time he believed that this excessively high level of tax burden could hamper economic growth (Tanzi, 2014a, pp. 3-20). Everything started to change with industrialization and then with the outbreak of the Great Depression and two world wars. Already in the 1920s, public expenditure started to rise gradually, with the introduction of a general income tax, followed (though much later) by a general consumption tax. At the same time, it should not be forgotten that economists themselves have contributed indirectly to these changes by formulating new development concepts justifying the need for state intervention in the economy. An important role here was undoubtedly played by Keynes, who in 1926 called for an 'end to laissez-faire', proposed an increase in the role of state in the economy, rejected the idea of market automatism in the regulation of the economy, and for the first time assigned taxes with important stimulative and redistributive functions ${ }^{2}$.

After the Second World War, tax policy became one of the main instruments for achieving socioeconomic goals. However, the pace of growth of public expenditure until the early 1960s was still quite slow. Evident acceleration have not taken place until between 1960 and 1980, when many industrialized countries decided to introduce economic protection for their citizens, creating, under strong internal pressure, the so-called welfare state. To compensate for the society's 'sacrifice' during the war, governments began to attach great importance to social welfare and income equalization (Tanzi, 2014a, pp. 3-20).

The 'new' economic role of the state turned out to be very expensive. The level of the tax burden started to rise at a high rate. At that time, the level

${ }^{2}$ See further in Keynes (2003, p. 336). 
of taxes in many developed countries exceeded $40 \%$ of GDP, but unfortunately the rate of growth of public expenditure was even higher. There was no other option but to achieve or maintain full employment, and current deficits were accepted as an instrument to stabilize the falling combined demand. However, it was a time of limited and controlled trade and exchange of capital. National tax policies did not go beyond national borders and in principle did not affect other jurisdictions. Individual countries could not only shape it freely, but also control it. According to Tanzi (2014a, pp. 3-20), the tax bases could then be compared to the waters of national lakes, "the water of which could be exploited at will only by the national governments of the countries in which the lakes were located. There was no fear of foreign tax competition or of global tax evasion...' During this period, governments rarely duplicated the patterns of other countries' tax systems, but at the same time had greater opportunities to raise tax rates without fear of loss of income.

In the pre-globalization era, state interventionism dominated mainly in the 1960s. At the end of the next decade, under the influence of intensifying inflation processes, the process of gradual reduction of public expenditure, especially of a social nature, was started. A revival of liberalism took place. From the early 1980s to the mid-1990s, in developed democracies, governments systematically reduced statutory income tax rates for both companies and individuals, eliminated tax reliefs and exemptions, thereby broadening the so-called tax base. At the same time, countries began to strive to balance their budgets (Fedorowicz, 1998, p. 141). In the theory of taxation, the idea of tax neutrality and the view that taxes should not interfere with economic processes began to play a greater role. Instead of being an instrument supporting the economy, they started to be seen as an instrument distorting prices and it was therefore considered that their impact should be limited to a minimum ${ }^{3}$.

In the 1990s, under the influence of the so-called Washington Consensus, the economic policies of many countries changed significantly. Economies became more open. The share of import and export in GDP of individual countries increased significantly. Capital began to move freely across national borders, and a global financial system was created. The role of international corporations also increased. Globalization, new technologies and changes in the structure of economies limited the 'national' tax base and made it difficult for governments to raise taxes. These difficulties were also largely due to increasing international tax competition, which in some cases has become clearly unfair. It was also caused by the growing phenomenon of tax evasion, especially in large enterprises, the so-called transnational companies (Tanzi, 2014a, pp. 3-20).

In the opinion of Tanzi (2014b, p. 498), it can be assumed that globalization has reduced the fiscal space of governments, while tax systems have become less progressive. Globalization, through its impact on tax systems, has therefore contributed to the growing inequalities in the distribution of income, the effects

${ }^{3}$ A detailed discussion on this subject can be found in Ahmad \& Stern (1989, pp. 1005-1092), Burgess \& Stern (1993, pp. 762-830), Dom \& Miller (2018). 
of which can now be seen in many countries, both developed and developing. Therefore, it can be concluded that by reducing the fiscal space of countries, globalization has also contributed to a reduction in the ability of governments to conduct redistribution policies implemented through public expenditure.

The global financial crisis once again raised the question of the role of the state in combating the economic and fiscal instability that results from the uncontrolled liberalization of trade and finances ${ }^{4}$. Even the IMF, which had advocated the liberalization of world capital markets, questioned the neoliberal consensus from before the economic and fiscal disaster (Ostry et al., 2016, pp. 38-41). Governments were confronted with the need to introduce tax reforms which would enable stabilization of the economy. It has also been realized that economic development requires the participation of all citizens in the growth process, in other words, in the pursuit of growth, social inequalities and the way in which income is distributed cannot be ignored (Tanzi, 2014b, pp. 491-506). Tax policy implemented after 2008, taking into account the specificity of individual economies, was undoubtedly supposed to support these processes.

\section{Methods}

The implementation of the assumed research objectives required the use of descriptive analysis and statistical methods. The Pearson's correlation coefficient was used to investigate linear correlations. The research covered a period of eleven years, i.e. 2007-2016. The year 2007 was taken as a base year. It was assumed that although the first signs of a crisis had already occurred in that year, the response to the recession through tax policy have not occurred until the following years. Due to the availability of comparable data on tax revenues, the year 2016 was adopted as the last year of this analysis. The research included panel data from 36 OECD countries. The tax policy implemented in the years 2007-2016 was analyzed, taking into account primarily the level and structure of taxes 5 in relation to GDP and the total tax revenues, changes in marginal PIT rates and in CIT rates. An increase in the tax-to-GDP ratio does not always mean that the amount of tax revenue increases in nominal or real terms. Changes in the tax-to-GDP ratio also result from relative changes in nominal tax revenues and nominal GDP. It should be noted that if tax revenue increases more than GDP (or falls less than GDP), the tax-to-GDP ratio will be increasing. Conversely, if tax revenue increases less than GDP or keeps falling, the tax-toGDP ratio will decrease (OECD, 2018, p. 23). Nevertheless, it has been assumed as a simplification that this ratio allows for comparison of changes in tax policies in the analyzed countries and is universal in nature. Due to the limited

\footnotetext{
${ }^{4}$ See further in Rodrik (2011, p. 368).
}

5 According to the OECD classification, taxes are defined as compulsory, unrequited payments to public administration. Taxes also include social security contributions (SSC) (OECD, 2018). 
size of the text, no correlation between changes in GDP and tax revenues over the period considered is presented in the research.

Moreover, using the Pearson correlation coefficient, linear relationships between the following variables were examined:

- tax revenue to the level of GDP and GDP per capita,

- the ratio of shares of income and consumption taxes in total tax revenues to the level of GDP and GDP per capita,

- the marginal rate for PIT to the level of GDP and GDP per capita,

- CIT rate to the level of GDP.

The research was conducted on the basis of statistical data of selected countries, published in the OECD Global Revenue Statistics Database.

\section{Results}

In the years 2007-2016, the average share of total tax revenues in OECD countries in relation to GDP increased only by $0.5 \mathrm{pp}$. (see table 1 ). The lowest average occurred in 2009 (32.2\%), the highest in 2016 (34.0\%), which means a change of $1.8 \mathrm{pp}$ only. In OECD countries, the tax-to-GDP ratio in 2017 ranged from $16.2 \%$ in Mexico to $51.6 \%$ in Iceland, while in 19 countries the ratio was below the OECD average of $34 \%$. At the same time, the tax-to-GDP ratio differed significantly per country over the period analyzed. In 2007 and 2016, the lowest share of taxes in GDP was recorded in Mexico (12\% and 16.6\%), while the highest in Denmark (46.4\%) in 2007 and in Iceland (51.6\%) in 2016. The difference between the lowest and the highest share in 2007 was $34.4 \mathrm{pp}$, whereas in 2016 it was $35 \mathrm{pp}$. At the same time, the highest increase in the share of taxes in GDP over the 11-year period (2007-2016) was recorded in Iceland (by $12.7 \mathrm{pp}$ ). An interesting fact is that this increase occurred mainly over 1 year and was not a result of tax increase ${ }^{6}$. Still in 2015, the ratio in Iceland was $36.3 \%$, while in the following year it was $51.6 \%$. The next country with the highest level of taxes in GDP was Denmark (46.2\%, a decrease compared to the base year by $0.2 \mathrm{pp})$.

The increase in the tax-to-GDP ratio in the years 2007-2016 was observed in 20 out of 36 countries (see table 2), with the highest growth (except for Iceland) in Greece and Mexico (by $7.7 \mathrm{pp}$ and $4.6 \mathrm{pp}$ ). Over the same period, 8 other countries (France, Finland, Netherlands, Germany, Portugal, Estonia, Slovak Republic, Japan) experienced an increase of this ratio by $2.5 \mathrm{pp}$. or more. At the same time, in countries where the share of taxes in GDP decreased in the period analyzed, as many as 9 saw in the last year (i.e. 2016) a renewed increase in this ratio in relation to the year-to-year ratio (2015/2016). Only 3 countries in 2016 had a share of taxes in GDP 3 pp lower than in 2007 (Norway, Spain, Ireland). Both in 2007 and 2016 (table 2) the largest number of the 36 countries surveyed (18 and 19 respectively) had tax rates measured as a share of GDP within the range of $30-40 \%$ (50\% and 53\% of the surveyed population

${ }^{6}$ In 2016, Iceland. 
respectively), the lowest (1 country in 2007 and 2016) within the range of 10$20 \%$ (3\% of the surveyed population).

The role of individual taxes in generating tax revenues was not uniform in the countries covered by the analysis. In 2016, the tax structure (measured by the share of particular taxes in total tax revenues) in OECD countries was diversified. Income taxes (both PIT and CIT) accounted for the largest share in the 16 countries surveyed, income from SSC dominated in 11 countries and consumption taxes accounted for the largest proportion in 8 countries. The role of other taxes as revenue for the budget in OECD countries was limited.

While the tax structure of individual countries was stable, the differences in the share of specific taxes between countries were significant (see chart 1). For example, in 2016 the PIT share ranged from a low level of 8.8\% and 10.2\% in Chile and Slovakia, to $40.8 \%$ in Australia and 53.5\% in Denmark. CIT share in 2016 was on average $9 \%$ (11.1\% in 2007) and ranged from 5\% (France, Iceland and Slovenia) to $20.9 \%$ (Chile) and $21.0 \%$ (Mexico).

In 2016, similarly as in 2007, the largest share in tax revenues in the analyzed OECD countries was held by income taxes (understood as total revenues of taxes on income, i.e. PIT and CIT, as well as profits and capital gains), 35.9\% and $33.6 \%$ respectively. In 2007, taxes on goods and services accounted for an average of $32 \%$ of total tax revenues in 36 countries, while in 2016 this ratio increased to $32.7 \%$. SSC accounted for $24.8 \%$ and $26.2 \%$ respectively. In 2007 , the highest share of income taxes in total tax revenues was recorded in New Zealand (62.9\%), Denmark (60.1\%) and Australia (59.3\%), while the lowest in Slovakia (20.9\%), Poland (22.8\%), Slovenia and Greece (23.3\%). In 2016, the highest share was recorded in Denmark (62.8\%), Australia (57.2\%) and New Zealand (55.6\%), the lowest in Hungary (19.3\%), Lithuania (18.9\%) and Slovenia $(18.8 \%)$.

In the years 2007-2016, the average share of direct ${ }^{7}$ taxes in total tax revenue decreased by $2.1 \mathrm{pp}$ (from $41.4 \%$ to $39.3 \%$ ). In 2016, the share of this ratio was lower than in 2007 in 24 countries, while in 12 countries it increased. The highest increase was recorded in Iceland by $16.6 \mathrm{pp}$. However, if we consider the data for this country concerning 2016 as unrepresentative, the highest growth occurred in Greece and amounted to 3 pp (increase from 28.6\% in 2007 to $31.6 \%$ in 2016). The highest decrease in the years $2007-2016$ by 12 pp was recorded in Chile (from 56.6\% to 38.6\%). In 2007, in 10 out of 36 countries analyzed ( $27.8 \%$ of the population surveyed), the share of direct taxes in total income was between $40-50 \%$, in 8 countries ( $22.2 \%$ of the population surveyed) between $20-30 \%$, and in 3 countries between $60-70 \%$ (8.3\% of the population). In 2016, these ratios were as follows: $40-50 \%-8$ countries $(22.2 \%)$, $20-30 \%-9$ countries $(25.0 \%), 60-70 \%-4$ countries (11.1\%). Therefore, the differences compared to 2007 were minor (see table 3).

7 The total value of taxes on income, profits and capital gains, taxes on property was taken into account in the calculation of the total value of direct taxes. 
In the years 2007-2016, the average share of indirect taxes (taxes on goods and services) in total tax revenues increased in 36 countries analyzed by $0.7 \mathrm{pp}$ from $32 \%$ to $32.7 \%$. As in the case of direct taxes, this ratio varied widely across individual jurisdictions. During the period analyzed, the share of indirect taxes in total revenue decreased in 15 countries and increased in 21 countries. The highest increase was recorded in Chile (by $10.8 \mathrm{pp}$ ) and the highest decrease in Iceland (by 17.1 pp). In 2007, the highest level of this ratio was recorded in Turkey (47.7\%), the lowest in the USA (16.8\%). Similarly, in 2016, the highest was recorded in Chile $54.6 \%$ (increase by 10.8 pp compared to 2007), the lowest in the USA 16.9\% (increase by 0.1 pp). In both 2007 and 2016, in 41.7\% of the countries analyzed, indirect taxes were in the range of $30-40 \%$ of total tax revenues. However, in 2016 in 19 jurisdictions analyzed this ratio was below the OECD average (similar to 2007, although these countries did not overlap).

The crisis also contributed to the change of tax rates in PIT. The progressiveness of this tax is evidenced, first and foremost, by the marginal rate. The average marginal rate in PIT (taking into account only central taxes) in the years 2007-2016 increased by 0.38 pp, from $35.41 \%$ to $35.79 \%$. During the period analyzed, the marginal PIT rate decreased in 11 countries, increased in 15 countries $^{8}$, and in 9 countries it was at the same level in 2016 as in 2007. The largest decrease in the marginal rate was recorded in Hungary by $21 \mathrm{pp}$, while the highest increase was recorded in Iceland by $9.05 \mathrm{pp}$. The highest marginal rate in 2007 was in force in the Netherlands (52\%, this rate did not increase within the entire period under consideration), whereas in 2016 it was in Austria (55\%, increase by 5 pp). The lowest in both 2007 and 2016 in Switzerland (11.5\%). Most countries had marginal rates ranging from $40 \%$ to $60 \%$ (see table 4 ), but it is not possible to state high progressiveness of this tax on this basis. However, if we additionally take into account the PIT rates applicable in some countries at the local level, the marginal PIT rate is clearly increasing (41.35\% in 2007, $43.07 \%$ in 2016). The distribution of countries in particular percentage ranges is also changing, in 201612 of them had a marginal PIT (central+subcentral) rate in the range of $50 \%$ and more.

The average CIT rate (excluding local additions) in the years 2007-2016 in OECD countries surveyed decreased by $2.06 \mathrm{pp}$ from $24.66 \%$ to $22.6 \%$. A decrease was recorded in 20 countries, while the rate increased in 6 countries and remained at the same level as in 2007 in 5 out of 36 (see table 5). The largest number of jurisdictions analyzed had a rate between 20\% and 30\% (19 in 2007, 21 countries in 2016, see table 5). The highest rate in 2007 and 2016 was applicable in the USA (35\%), the lowest within the entire period analyzed in Switzerland (8.5\%). In 2011-2015, a higher CIT rate than in the USA was recorded in France $(36.1 \%, 36.1 \%, 38 \%, 38 \%$ and 38\% respectively, in 2016 France lowered its CIT rate to $34.4 \%)$.

8 The survey covered 35 countries. The OECD database does not provide the rates applicable in Lithuania. 


\section{Discussion}

The OECD average hides a large variation in national tax revenue in relation to GDP. The levels of taxation measured by the tax-to-GDP ratio and the structure of tax revenues in the years 2007-2016 in 36 OECD countries were not uniform. These differences are not only due to different decisions concerning the implemented tax policies. They are above all determined by history, economy and politics, which is a kind of a 'basis'. However, given the trend in the average tax-to-GDP ratio, some similarity can be observed in the OECD countries analyzed: a decrease in tax levels as a result of the recession and then its another increase, slow, but stable. In only a few of the countries analyzed was the share of taxes in GDP lower in 2016 than in 2007 by 3 pp and more. This concerns Norway, Spain and Ireland. It can be assumed that international tax competition was taken into account when deciding on the direction of tax policy. In most of the countries surveyed (18 in 2007 and 19 in 2019), taxation was at an average level of $30-40 \%$ of GDP.

However, it should be borne in mind that a lower tax-to-GDP ratio does not always mean that the amount of tax revenue has decreased in nominal or real terms. If, for example, tax revenue increases to a lesser extent, this ratio will also be lower. This is confirmed by the results of Pearson's linear correlation. Between the amount of tax revenues (total: PIT, CIT, profits and capital gains as a percentage of GDP) and the level of GDP there is a significant weak negative correlation. The value of the Pearson Ratio is -0.21843318 . On the other hand, a significant moderate positive correlation exists between the amount of income tax revenues (as a percentage of GDP) and the amount of GDP per capita, the value of Pearson's coefficient is 0.52387340 (see chart 2). The positive nature of this correlation means that with the growth of GDP per capita, an increase in the share of income tax revenues in GDP can be observed. There is no doubt that richer societies are willing to accept a higher tax burden on this account for higher quality of public services in return.

Among OECD countries, despite some general similarities in trends in the direction of tax changes, there is still considerable heterogeneity in the levels and structure of taxation. In 2016, only in 6 of them the average tax structure differed from the average OECD structure by less than 20\% (OECD, 2018, p. 52). At the same time, however, it can be stated that 'in 2016, the OECD average was more representative of the underlying distribution than at any point in the preceding 20 years' (OECD, 2018, p. 54).

In 2016, the central budgets of OECD countries were still dominated by income tax revenues (33.6\%). However, their average share in total tax revenues in 2016 as compared to 2007 decreased by 2.3 pp. A similar trend could be observed in most of the jurisdictions analyzed. Only 8 countries saw a slight increase in this ratio, to a maximum of $2.7 \mathrm{pp}$ in Denmark. The average share of consumption taxes in the OECD countries analyzed was 32.7\% (an increase 
of 0.7 pp compared to 2007), in as many as 25 countries this ratio was higher than in 2007.

The advantage of income tax in the revenue structure is undoubtedly characteristic of larger developed economies. The higher the development measured by GDP per capita, the higher the share of income taxes and the lower the consumption taxes in total tax revenues. This is confirmed by Pearson's linear correlation, on the basis of which a statistically significant, moderate positive correlation was found between the value of the ratio (income tax revenues to consumption tax revenues) and GDP as well as GDP per capita. The value of the Pearson coefficients was $0.50877539,0.56457121$ respectively (see chart 3 and chart 4).

Nevertheless, on the basis of the observations made, it should be concluded that the predominance of income taxes as a source of public income is systematically decreasing. VAT provides OECD countries not only with an efficient source of income, but also with a very good instrument to stabilize public finances, especially in times of recession. In contrast to PIT, VAT revenues can be changed by modifying one fixed feature (rate). In addition, this change can have an immediate impact on revenue, as VAT revenue is not subject to significant delays in collecting receivables, as is the case with PIT and CIT (Tanzi, 2010, pp. 1-38). This is particularly important in times of economic crises, when GDP is falling. There is a statistically significant, moderate negative correlation between the share of consumption taxes and GDP. Pearson's correlation coefficient is 0.54335626 (see chart 5).

\section{Conclusion}

Economic globalization has changed the dynamics of the legislation process and influenced decision making in the field of tax policy. Although decisions are still made by state parliaments, they not only reflect the needs of the budget, but also ensure the international competitiveness of the tax system and provide protection against fiscal erosion. It should be remembered, however, that a tax system is defined as a social agreement of sorts, concluded between the government and the society, which is historically, economically and politically conditioned. The level and structure of taxation determine the specific 'social balance' achieved between the conflicting interests represented by the two parties to the agreement. This balance should not be disturbed solely in order to cover unitary shortfalls in public revenue in a given year. Decisions to change/reform the tax system should only be taken in order to achieve long-term objectives.

The conducted research confirmed that the level of taxation and tax structures in OECD countries are increasingly similar to each other, although they are still clearly heterogeneous. Tax policy is determined not only by the individual needs of a given society, but also by the global economic situation as well as tax competition. The above analysis does not exhaust the issue undertaken. It does not answer all the specific questions about the factors shaping different tax 
levels and structures as well as structural similarities occurring within certain groups of OECD countries. Future research work should certainly clarify these issues. It should be emphasized that studies of existing tax reforms and their conditions are crucial to assess the impact of future changes in this area which, at least partly, should allow to avoid mistakes in the future.

\section{References}

Ahmad, E. \& Stern, N. (1989). Taxation for developing countries. In H. Chenery, \& T.N. Srinivasan (Eds.), Handbook of development economics, Vol. 2. Amsterdam: North-Holland.

Bird, R.M. \& Wilkie, J.S. (2012). Designing tax policy: constraints and objectives in an open economy. International Center for Public Policy Working Paper, $12-24$.

Burgess, R. \& Stern, N. (1993). Taxation and Development. Journal of Economic Literature, 31(2).

Dom, R. \& Miller, M. (2018). Reforming tax system in the developing world. Retrieved 16.03.2019 from https://www.odi.org.

Fedorowicz, Z. (1998). Polityka fiskalna. Poznań: WSB.

Keynes, J.M. (2003). Ogólna teoria zatrudnienia, procentu i pieniądza. Warszawa: PWN.

OECD. (2018). Revenue statistics 2018. doi:10.1787/rev_stats-2018-en.

OECD. (2019). Global revenue statistics database. Retrieved 01.03.2019 from https://stats.oecd.org.

Ostry, J.D., Loungani, P., \& Furceri, D. (2016). Neoliberalism: oversold? Finance \& Development, 53(2).

Rodrik, D. (2011). The globalization paradox: democracy and the future of the world economy. New York: W.W. Norton.

Tanzi, V. (2010). Tax systems in the OECD: recent evolution, competition and convergence. International Studies Program Working Paper, 10-12.

Tanzi, V. (2014a). Globalization and taxation: a brief historical survey. Rivista di diritto finanziario e scienza delle finanze, 73(1).

Tanzi, V. (2014b). Taxation and equitable economic development: a historical note. Rivista di Diritto Finanziario e Scienza delle Finanze, 73(4).

\section{Acknowledgements}

Author contributions: author has given an approval to the final version of the article.

Funding: this research was funded by the University of Białystok statutory sources.

Note: the results of this study were presented at 10th International Conference on Applied Economics Contemporary Issues in Economy (June 27-28, 2019, Torun, Poland). 


\section{Appendix}

Table 1.

Total tax revenues in OECD countries in the years 2007-2016 (in \% of GDP)

\begin{tabular}{|c|c|c|c|c|c|c|c|c|c|c|c|}
\hline Country & 2007 & 2008 & 2009 & 2010 & 2011 & 2012 & 2013 & 2014 & 2015 & 2016 & 2007-2016 \\
\hline Iceland & 38.9 & 35.0 & 31.7 & 33.2 & 34.3 & 35.0 & 35.6 & 38.3 & 36.3 & 51.6 & 12.7 \\
\hline Denmark & 46.4 & 44.8 & 45.0 & 44.8 & 44.8 & 45.5 & 45.9 & 48.5 & 46.1 & 46.2 & -0.2 \\
\hline France & 42.5 & 42.3 & 41.5 & 42.1 & 43.3 & 44.4 & 45.4 & 45.4 & 45.3 & 45.5 & 2.9 \\
\hline Belgium & 42.7 & 43.3 & 42.4 & 42.6 & 43.1 & 44.2 & 45.1 & 45.1 & 44.8 & 44.1 & 1.4 \\
\hline Sweden & 45.0 & 44.0 & 44.1 & 43.2 & 42.5 & 42.6 & 42.9 & 42.6 & 43.1 & 44.0 & -0.9 \\
\hline Finland & 41.5 & 41.2 & 40.9 & 40.8 & 42.0 & 42.7 & 43.6 & 43.8 & 43.9 & 44.0 & 2.5 \\
\hline Italy & 41.7 & 41.7 & 42.1 & 41.9 & 41.9 & 43.9 & 44.1 & 43.5 & 43.1 & 42.6 & 0.9 \\
\hline Austria & 40.5 & 41.4 & 41.0 & 41.0 & 41.1 & 41.8 & 42.6 & 42.7 & 43.1 & 42.2 & 1.7 \\
\hline Hungary & 39.4 & 39.5 & 38.9 & 37.3 & 36.3 & 38.4 & 37.9 & 38.0 & 38.7 & 39.2 & -0.2 \\
\hline Greece & 31.2 & 31.0 & 30.6 & 32.0 & 33.6 & 35.5 & 35.5 & 35.7 & 36.6 & 38.8 & 7.7 \\
\hline Norway & 42.1 & 41.4 & 41.2 & 41.9 & 42.0 & 41.5 & 39.9 & 38.8 & 38.4 & 38.7 & -3.4 \\
\hline Netherlands & 35.7 & 35.9 & 34.9 & 35.7 & 35.4 & 35.6 & 36.1 & 37.0 & 37.0 & 38.4 & 2.7 \\
\hline Luxembourg & 36.1 & 36.6 & 38.2 & 37.4 & 37.0 & 38.4 & 38.3 & 37.4 & 37.1 & 38.1 & 2.1 \\
\hline Germany & 34.9 & 35.4 & 36.1 & 35.0 & 35.7 & 36.4 & 36.8 & 36.7 & 37.0 & 37.4 & 2.5 \\
\hline Slovenia & 37.1 & 36.4 & 36.2 & 36.9 & 36.5 & 36.8 & 36.4 & 36.2 & 36.4 & 36.5 & -0.6 \\
\hline Portugal & 31.8 & 31.7 & 29.9 & 30.4 & 32.3 & 31.8 & 34.1 & 34.3 & 34.4 & 34.3 & 2.5 \\
\hline Czech Republic & 34.2 & 33.5 & 32.3 & 32.5 & 33.3 & 33.7 & 34.1 & 33.1 & 33.3 & 34.2 & 0.0 \\
\hline OECD (average) & 33.6 & 32.9 & 32.2 & 32.3 & 32.6 & 33.1 & 33.4 & 33.6 & 33.7 & 34.0 & 0.5 \\
\hline Estonia & 31.3 & 31.4 & 34.9 & 33.3 & 31.5 & 31.7 & 31.6 & 32.3 & 33.3 & 33.7 & 2.5 \\
\hline Poland & 34.6 & 34.1 & 31.2 & 31.4 & 31.8 & 32.1 & 31.9 & 31.9 & 32.4 & 33.4 & -1.2 \\
\hline Spain & 36.4 & 32.1 & 29.7 & 31.2 & 31.2 & 32.1 & 32.9 & 33.6 & 33.6 & 33.2 & -3.2 \\
\hline United Kingdom & 33.0 & 32.3 & 31.2 & 32.3 & 33.2 & 32.4 & 32.2 & 31.8 & 32.2 & 32.7 & -0.2 \\
\hline Canada & 32.6 & 31.3 & 32.4 & 31.1 & 30.9 & 31.3 & 31.2 & 31.3 & 32.7 & 32.7 & 0.1 \\
\hline Slovak Republic & 29.2 & 29.0 & 289 & 28.1 & 28.6 & 28.3 & 30.2 & 31.1 & 32.2 & 32.4 & 3.2 \\
\hline New Zealand & 33.9 & 32.9 & 30.2 & 30.3 & 30.1 & 31.6 & 30.5 & 31.2 & 31.6 & 31.6 & -2.3 \\
\hline Israhel & 34.2 & 32.0 & 29.8 & 30.7 & 30.9 & 30.0 & 30.8 & 31.2 & 31.3 & 31.3 & -2.9 \\
\hline Japan & 27.5 & 27.4 & 26.0 & 26.5 & 27.5 & 28.2 & 28.9 & 30.3 & 30.6 & 30.6 & 3.0 \\
\hline Latvia & 28.2 & 27.8 & 28.0 & 28.2 & 27.8 & 28.6 & 28.6 & 29.0 & 29.2 & 30.4 & 2.2 \\
\hline Lithuania & 30.0 & 30.6 & 30.2 & 28.3 & 27.2 & 27.0 & 27.0 & 27.5 & 28.9 & 29.8 & -0.2 \\
\hline Switzerland & 26.2 & 26.6 & 27.0 & 26.6 & 26.9 & 26.9 & 27.0 & 26.9 & 27.6 & 27.8 & 1.6 \\
\hline Australia & 29.6 & 26.9 & 25.6 & 25.3 & 25.9 & 27.0 & 27.2 & 27.3 & 27.9 & 27.8 & -1.8 \\
\hline Korea & 24.8 & 24.6 & 23.8 & 23.4 & 24.2 & 24.8 & 24.3 & 24.6 & 25.2 & 26.2 & 1.5 \\
\hline United States & 26.7 & 25.7 & 23.0 & 23.5 & 23.9 & 24.1 & 25.7 & 26.0 & 26.2 & 25.9 & -0.8 \\
\hline Turkey & 23.1 & 23.1 & 23.5 & 24.8 & 25.9 & 24.9 & 25.3 & 24.6 & 25.1 & 25.3 & 2.2 \\
\hline Ireland & 30.4 & 28.5 & 27.3 & 27.0 & 27.4 & 27.6 & 28.2 & 28.4 & 23.1 & 23.3 & -7.1 \\
\hline Chile & 22.7 & 21.4 & 17.3 & 19.6 & 21.1 & 21.3 & 19.9 & 19.6 & 20.4 & 20.2 & -2.5 \\
\hline Mexico & 12.0 & 12.6 & 12.5 & 12.8 & 12.8 & 12.6 & 13.3 & 13.7 & 15.9 & 16.6 & 4.6 \\
\hline
\end{tabular}

Source: Own preparation based on OECD (2019). 
Table 2.

The level of taxation in OECD countries (in \% of GDP)

\begin{tabular}{lcccc}
\hline \multirow{2}{*}{ Range (in \%) } & \multicolumn{2}{c}{2007} & \multicolumn{2}{c}{2016} \\
\cline { 2 - 5 } & number of countries & share (in \%) & number of countries & share (in \%) \\
\hline $10-20$ & 1 & 3 & 1 & 3 \\
$20-30$ & 9 & 25 & 8 & 22 \\
$30-40$ & 18 & 50 & 19 & 53 \\
$40-50$ & 8 & 22 & 7 & 19 \\
$50-60$ & 0 & 0 & 36 & 3 \\
total & 36 & 100 & & 100 \\
\hline
\end{tabular}

Source: Own preparation based on OECD (2019).

Table 3.

Share of direct taxes in total tax revenues in OECD countries by percentage range

\begin{tabular}{lcccr}
\hline \multirow{2}{*}{ Range (in \%) } & \multicolumn{2}{c}{2007} & \multicolumn{2}{c}{2016} \\
\cline { 2 - 5 } $0-10$ & number of countries & share (in \%) & number of countries & share (in \%) \\
$10-20$ & 0 & 0.0 & 0 & 0.0 \\
$20-30$ & 0 & 0.0 & 0 & 0.0 \\
$30-40$ & 8 & 22.2 & 9 & 25.0 \\
$40-50$ & 8 & 22.2 & 12 & 33.3 \\
$50-60$ & 10 & 27.8 & 8 & 22.2 \\
$60-70$ & 7 & 19.5 & 3 & 8.3 \\
total & 3 & 8.3 & 4 & 11.2 \\
\hline
\end{tabular}

Source: Own preparation based on OECD (2019).

Table 4 .

The number of OECD countries with a marginal PIT rate in percentage classes

\begin{tabular}{ccccccccccc}
\hline$\%$ & 2007 & 2008 & 2009 & 2010 & 2011 & 2012 & 2013 & 2014 & 2015 & 2016 \\
\hline$<10,20)$ & 2 & 3 & 3 & 4 & 5 & 5 & 3 & 3 & 3 & 3 \\
$<20,30)$ & 9 & 9 & 9 & 6 & 6 & 6 & 7 & 7 & 8 & 7 \\
$<30,40)$ & 8 & 8 & 8 & 10 & 9 & 9 & 9 & 9 & 8 & 9 \\
$<40,50)$ & 13 & 12 & 12 & 11 & 11 & 11 & 11 & 11 & 11 & 11 \\
$<50,60)$ & 3 & 3 & 3 & 4 & 4 & 4 & 5 & 5 & 5 & 5 \\
\hline
\end{tabular}

Source: Own preparation based on OECD (2019). 
Table 5.

Number of OECD countries with CIT rate in percentage classes

\begin{tabular}{ccccccccccc}
\hline \multicolumn{1}{c}{$\%$} & 2007 & 2008 & 2009 & 2010 & 2011 & 2012 & 2013 & 2014 & 2015 & 2016 \\
\hline$<0,10)$ & 1 & 1 & 1 & 1 & 1 & 1 & 1 & 1 & 1 & 1 \\
$<10,20)$ & 7 & 9 & 8 & 11 & 9 & 10 & 9 & 9 & 9 & 9 \\
$<20,30)$ & 19 & 19 & 20 & 16 & 19 & 17 & 19 & 19 & 21 & 21 \\
$<30,40)$ & 9 & 7 & 7 & 8 & 7 & 8 & 7 & 7 & 5 & 5 \\
\hline
\end{tabular}

Source: Own preparation based on OECD (2019).

Chart 1.

Tax structures in 2016 (in \% of total tax revenue)

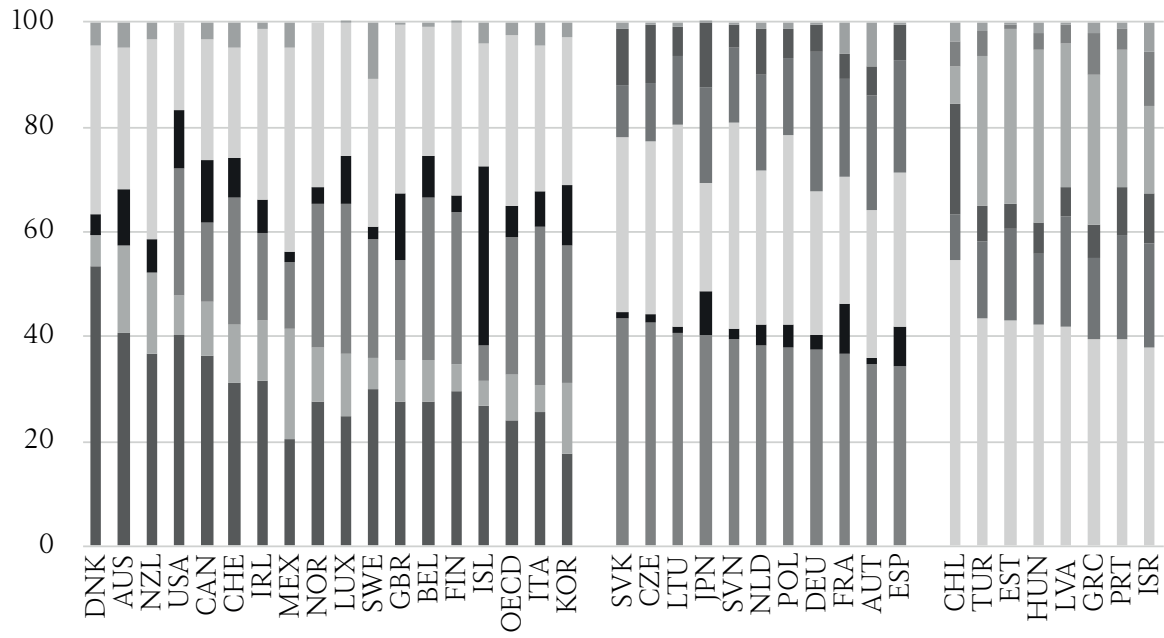

$\square$ PIT $\square$ CIT $\square$ social security contributions $\square$ property taxes $\square$ taxes on goods and services $\square$ other

Notes:

Countries are grouped and ranked by those where income tax revenues (personal and corporate) form the highest share of total tax revenues, followed by those where social security contributions, or taxes on goods and services, form the highest share.

The OECD average tax structure excludes the one-off revenues from stability contributions in Iceland. Source: Own preparation based on OECD (2018, p. 28). 


\section{Chart 2.}

Dispersion of tax income (in \% GDP) to GDP per capita (current PPPs, K USD)

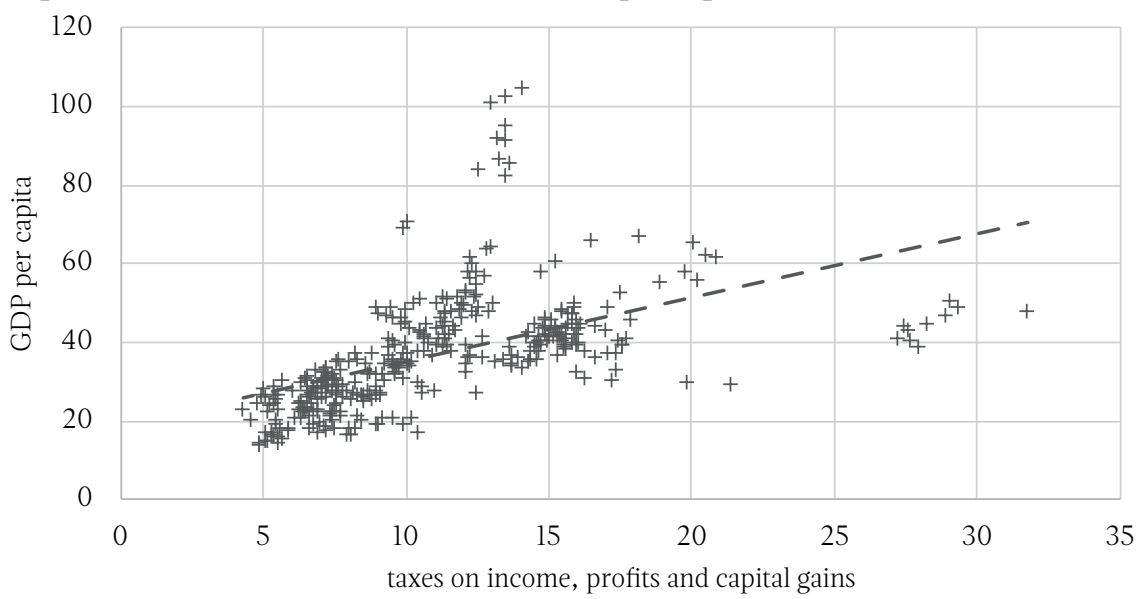

Notes:

Pearson's linear correlation $\mathrm{r}=0.52387340$.

Source: Own preparation based on OECD (2019).

\section{Chart 3.}

Dispersion of taxes income/taxes on goods and services to GDP (current prices, bn USD)

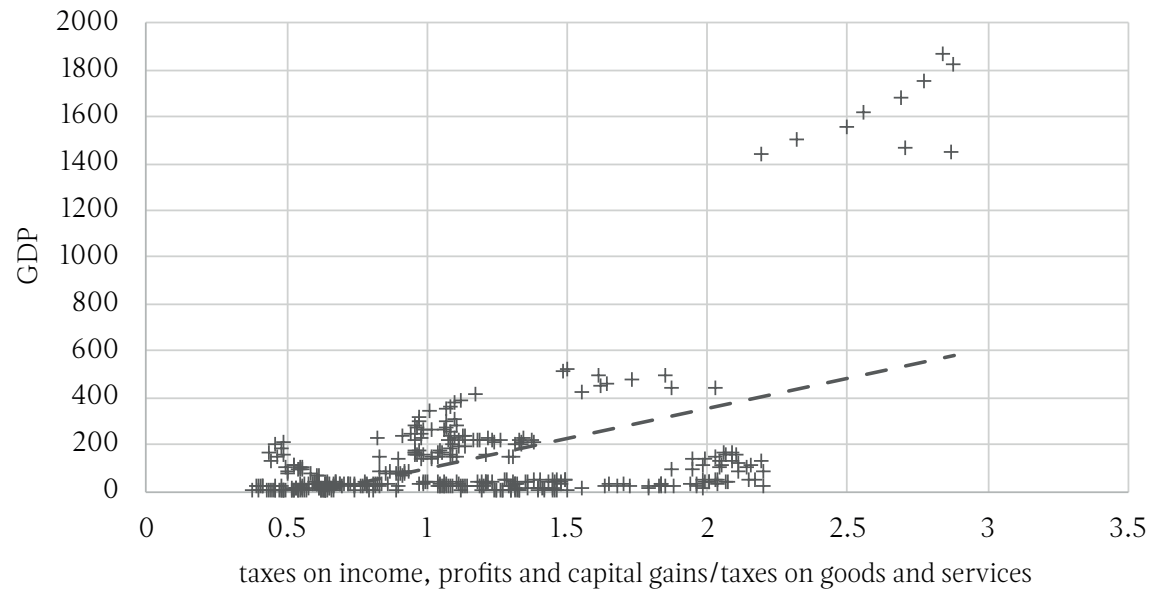

Notes:

Pearson's linear correlation $r=0.50877539$.

Source: Own preparation based on OECD (2019). 


\section{Chart 4.}

Dispersion of taxes income/taxes on goods and service to GDP per capita (current PPPs, K USD)

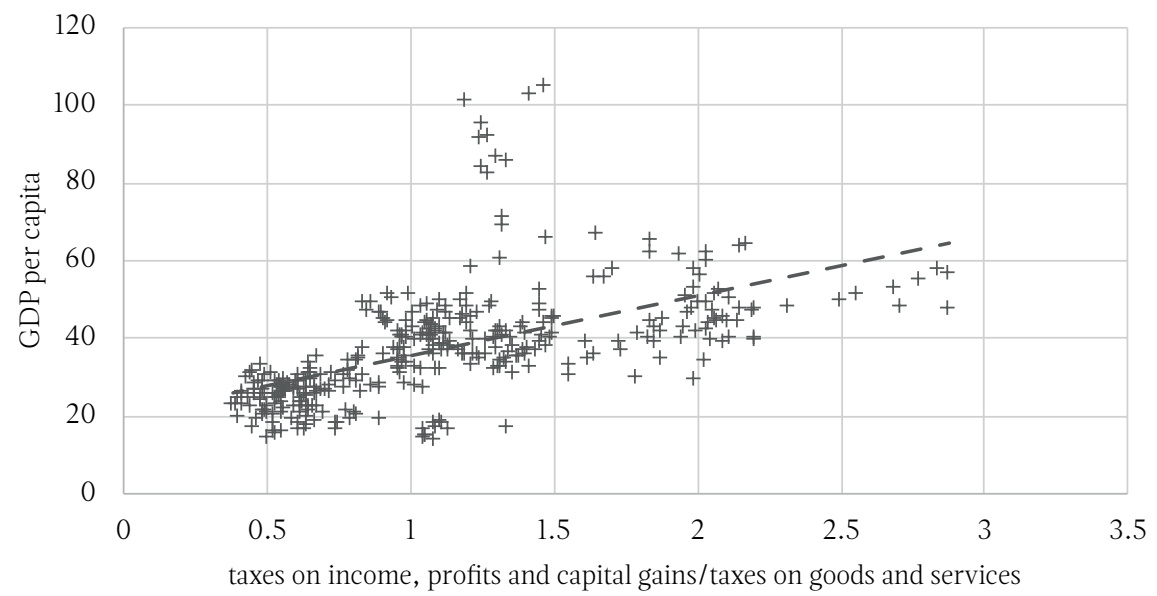

Notes:

Pearson's linear correlation Pearson $r=0.56457121$.

Source: Own preparation based on OECD (2019).

\section{Chart 5.}

Distribution of taxes on goods and service (in \% GDP) to GDP (bn USD)

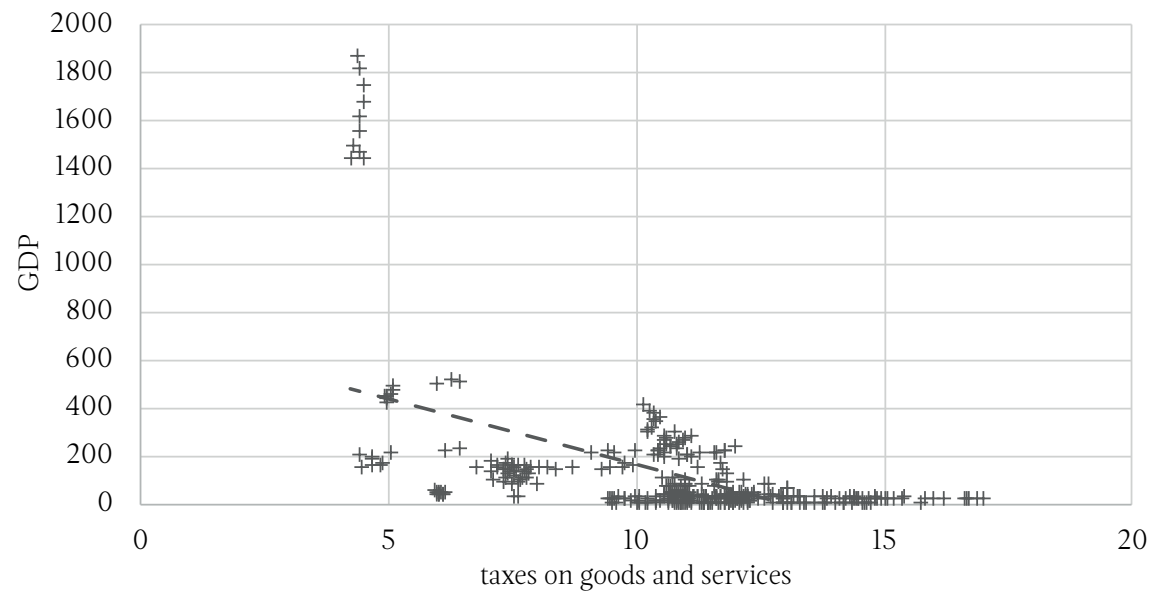

Notes:

Pearson's linear correlation $r=0.54335626$.

Source: Own preparation based on OECD (2019). 